\title{
Food system sustainability for health and well-being of Indigenous Peoples
}

\author{
Harriet V Kuhnlein *
}

Centre for Indigenous Peoples' Nutrition and Environment and School of Dietetics and Human Nutrition, McGill University, Macdonald Campus, 21,111 Lakeshore Road, Ste. Anne de Bellevue, QC H9X 3V9, Canada

Submitted 10 April 2014: Final revision received 4 October 2014: Accepted 10 November 2014: First published online 19 December 2014

\begin{abstract}
Objective: To describe how Indigenous Peoples understand how to enhance use of their food systems to promote sustainability, as demonstrated in several food-based interventions.

Design: Comments contributed by partners from case studies of Indigenous Peoples and their food systems attending an international meeting were implemented with public health interventions at the community level in nine countries.

Setting: The Rockefeller Foundation Bellagio Conference Center in Bellagio, Italy, where experiences from case studies of Indigenous Peoples were considered and then conducted in their home communities in rural areas.

Subjects: Leaders of the Indigenous Peoples' case studies, their communities and their academic partners.

Results: Reported strategies on how to improve use of local food systems in case study communities of Indigenous Peoples.

Conclusions: Indigenous Peoples' reflections on their local food systems should be encouraged and acted upon to protect and promote sustainability of the cultures and ecosystems that derive their food systems. Promoting use of local traditional food biodiversity is an essential driver of food system sustainability for Indigenous Peoples, and contributes to global consciousness for protecting food biodiversity and food system sustainability more broadly. Key lessons learned, key messages and good practices for nutrition and public health practitioners and policy makers are given.
\end{abstract}

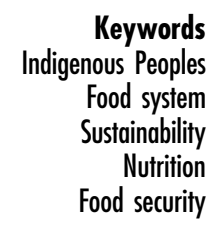

Health and well-being are closely linked to foods and diets provided by food systems, as all public health nutrition practitioners know. Our global population is constantly expanding and is expected to reach 9-10 billion people by 2050. Almost half of our global citizens now experience food shortages and food and nutrition insecurity to the extent that they cannot have active and healthy lives, they have outright undernutrition or micronutrient deficiencies, or else experience overweight or obesity ${ }^{(1,2)}$. Increased scrutiny of global food resources and food security has brought attention to shrinking diversity in major food crops in national diets. As global averages of per capita energy, protein, fat and weight of food consumed have increased over the last 50 years, an international homogeneity in major food supplies is evident ${ }^{(3)}$. At the same time, the increasing agricultural intensification and global use of meat and dairy foods have reduced dietary sustainability and contributed to environmental degradation and biodiversity loss ${ }^{(4-6)}$.

The approximately 400 million Indigenous Peoples in the world today are counted, more often than not, among those at serious health risk because of marginalization and disparities faced in social, economic and environmental conditions $^{(7,8)}$. It is a global human rights embarrassment that Indigenous Peoples face these disparities while living in rural ecosystems with knowledge and experience in long-evolved cultures, and who have food systems grounded with biodiverse plant and animal foods. Many retain the cultural practices to harvest and use these for family nutrition and health, but face daunting impediments in doing so because of ecosystem threats from others who covet their resources.

Sustainable diets are defined as '... those diets with low environmental impacts which contribute to food and nutrition security and to healthy life for present and future generations. Sustainable diets are protective and respectful of biodiversity and ecosystems, culturally acceptable, accessible, economically fair and affordable; nutritionally adequate, safe and healthy; while optimizing natural and human resources, ${ }^{(9)}$. Sustainable diets must be derived from sustainable food systems that are in turn derived from sustainable cultures and sustainable ecosystems. For cultures of 
Indigenous Peoples to have survived for thousands of years in particular ecosystems, their food systems, if intact, are then by definition sustainable, while recognizing that change and evolution are regularly experienced in natural ecosystems. However, because of globalized food markets the food systems of most Indigenous Peoples today, even those in very remote rural areas, are increasingly composed of a mixture of their traditional local foods and foods purchased from commercial outlets, creating an ever-increasing loss of local biodiversity, dietary quality, unsustainability and food insecurity for these populations. This results in malnutrition, especially for micronutrients, and overconsumption of dietary energy that drives the well-documented growing epidemic of obesity and chronic disease in many indigenous areas in the world today ${ }^{(7)}$.

Understanding how Indigenous Peoples perceive sustainability of their food systems that are now composed of both traditional and commercial foods provides a unique view on food system sustainability. Knowing how specific communities of Indigenous Peoples' cultures in rural settings in diverse ecosystems deal with improving use of their local food system for food and nutrition security gives useful insights to the global picture of sustainable food systems. For Indigenous Peoples, this information contributes to capacity building to strengthen ownership of local food security, despite the many different challenges of marginalization, land rights and development needs experienced in different parts of the world.

\section{Objective and setting}

The objective of the present paper is to describe the ideas of leaders of several cultures of Indigenous Peoples and their academic partners and how these were implemented in a long-term programme to improve nutrition, health and well-being by working closely within their local food systems. During the process of documenting the food biodiversity in twelve cultures in diverse ecosystems ${ }^{(8)}$, ideas for interventions to foster improved use of their local food systems were captured in a pre-Congress workshop of the International Union of Nutritional Sciences (IUNS) held in Futululu, South Africa ${ }^{(10)}$. Interventions in communities $^{(11)}$ were planned to develop the concepts of long-term sustainability of the food systems and were considered at a meeting of the research collaborators at the Rockefeller Foundation Center in Bellagio, Italy. The paper summarizes the thinking, rationale and suggested activities to promote Indigenous Peoples' food system sustainability, how these have been implemented by the people directly involved in the selected settings, and the major impacts and outcomes. The paper concludes with important key lessons learned, key messages and practices for nutrition and public health practitioners and policy makers to ensure better food security for Indigenous Peoples with increasing food system sustainability.

\section{Methods}

\section{Developing the research process}

Interdisciplinary team members from the Centre for Indigenous Peoples' Nutrition and Environment (CINE) based at McGill University, Montreal ${ }^{(12)}$, in cooperation with the Nutrition Division of the FAO and the IUNS, developed a comprehensive programme in 2001 that continued for more than 10 years. A methodology was developed by CINE with five cultures of rural-dwelling Indigenous Peoples in Asia (Bhil, Dalit, Karen, Miao and Mogh) ${ }^{(13)}$ that was then implemented over several years to document traditional food systems in twelve cultures of Indigenous Peoples in different parts of the world (Fig. 1). Important components of this documentation were to scientifically identify the many different food species and their components used for food, and then use local food science and nutrition laboratories to conduct nutrient composition analyses of key local species. Nine of these twelve case studies then subsequently proceeded to develop and conduct scientifically based nutrition and health education and promotion intervention programmes to increase use of local foods, as well as healthy commercial foods, to improve food and nutrition security and well-being. During these unique projects case study leaders met several times to develop the activities and policies to foster successful health promotion and food security based on local food systems ${ }^{(11)}$.

This work with indigenous communities regularly addressed the dichotomy of contemporary diets experienced by Indigenous Peoples, in that the diet contains two basic components: (i) traditional, locally accessed foods within the culture; and (ii) foods that are commercially available, often industrially produced and/or purchased in markets. Communities in very rural areas, with access to few commercial foods, have most dietary energy derived from biodiverse species; whereas communities closer to commercial centres usually have more dietary energy from less biodiverse and less nutrient-dense items ${ }^{(14)}$. The foodbased interventions, primarily education in nature, stressed the positive nutrient composition attributes of foods and the ability of communities to retain and enhance their local food systems as much as possible within local ecosystems, and to educate on the principles of costeffective and healthy purchased food choices.

\section{Results}

\section{Recognizing ecosystem threats to Indigenous Peoples' food systems}

For all Indigenous Peoples, the connection to land and place is the foundation of culture and population health ${ }^{(7)}$. An important first step in understanding ecosystem potential for ensuring sustainability of the food systems is recognition of ecosystem threats that affect local cultural foods. Table 1 presents a formidable list of current barriers to sustainable 


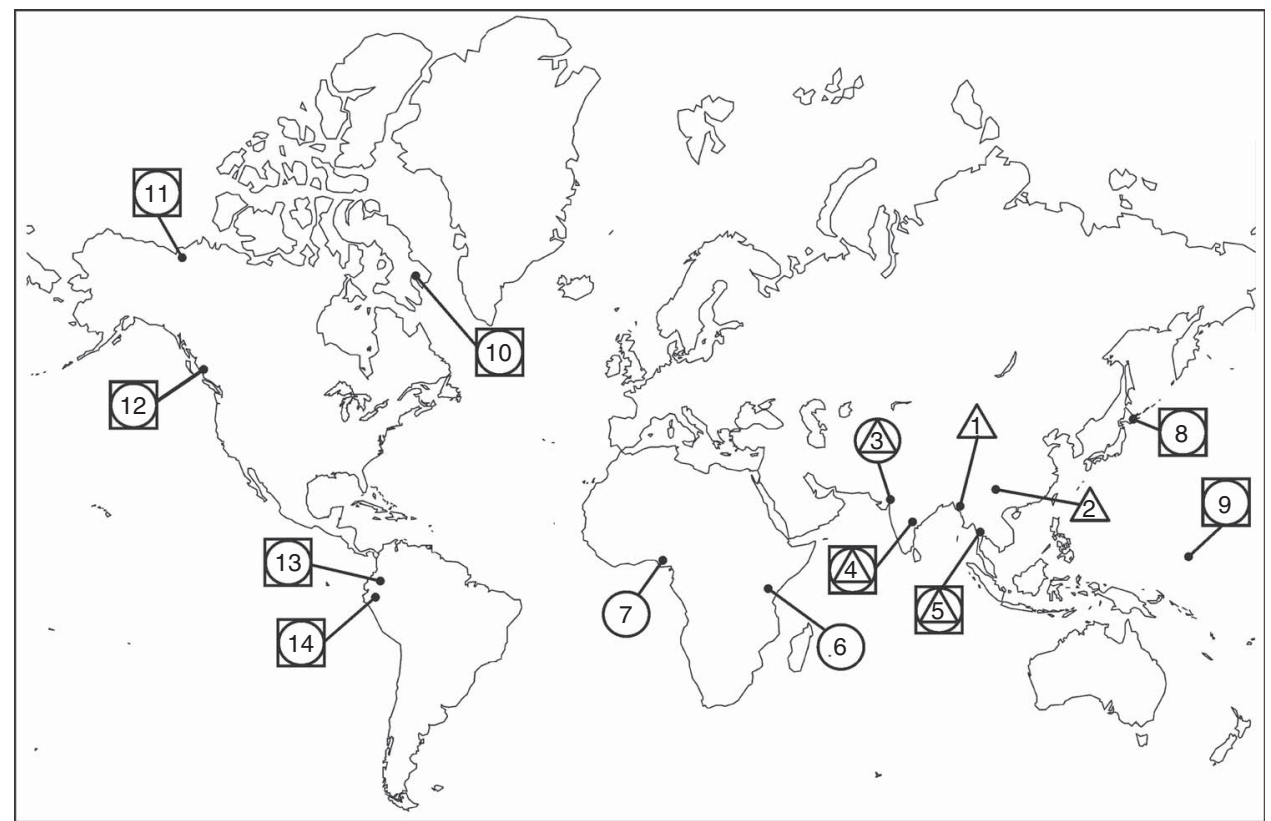

Fig. 1 Location of fourteen communities of Indigenous Peoples in the CINE (Centre for Indigenous Peoples' Nutrition and Environment) Global Health Project: 1, Mogh (Bangladesh); 2, Miao (Szechuan, China); 3, Bhil (Dang, Gujarat, India); 4, Dalit (Zaheerabad, Andhra Pradesh, India); 5, Karen (Kanchanaburi, Thailand); 6, Maasai (Kajiado, Kenya); 7. Igbo (south-eastern Nigeria); 8, Ainu (Hokkaido, Japan); 9, Pohnpei (Federated States of Micronesia); 10, Inuit (Pangnirtung, Nunavut, Canada); 11, Gwich'in (Northwest Territories, Canada); 12, Nuxalk (British Columbia, Canada); 13, Ingano (Caqueta, Colombia); 14, Awajún (Cenepa, Peru). Triangle indicates communities participating in the development of methods ${ }^{(13)}$; circle indicates communities participating in food system documentation ${ }^{(8)}$; square indicates communities participating in food system interventions ${ }^{(11)}$ (reproduced with permission from Journal of Ethnobiology (2014) 34, 17)

Table 1 Ecosystem threats reported to affect food systems in case study communities of Indigenous Peoples*

\begin{tabular}{|c|c|c|}
\hline Source/type of ecosystem impact & Examples/food system impact & References \\
\hline Erosion of biodiversity (wild species) & $\begin{array}{l}\text { Threats to caribou calving grounds from natural gas pipeline and } \\
\text { oil drilling in Arctic regions; widespread loss of tropical forests; } \\
\text { decreased yield and availability of certain foods (e.g. ooligan for } \\
\text { Nuxalk; wild fish and shellfish species, and wild game in many } \\
\text { places) }\end{array}$ & $21,25,28,35,36$ \\
\hline $\begin{array}{l}\text { Erosion of biodiversity (cultivated } \\
\text { species) }\end{array}$ & $\begin{array}{l}\text { Decreased use and loss of cultivated varieties (cultivars or } \\
\text { landraces; e.g. traditional cereals, banana varieties, taro, } \\
\text { breadfruit); threats from large-scale monocultures and GM food } \\
\text { crops }\end{array}$ & $22,23,27,37-39$ \\
\hline $\begin{array}{l}\text { Deforestation and over-exploitation of } \\
\text { forest resources }\end{array}$ & $\begin{array}{l}\text { Destruction of forests through logging and illicit crop cultivation; } \\
\text { overharvesting of rubber; deforestation through charcoal } \\
\text { making and firewood harvesting }\end{array}$ & $22,27,37,38,40,41$ \\
\hline Water shortages & $\begin{array}{l}\text { Drought, desertification; acute shortages of water for livestock } \\
\text { and household use }\end{array}$ & $40-42$ \\
\hline Hydroelectric dam construction & $\begin{array}{l}\text { Loss of salmon and other indigenous foods; changes in } \\
\text { environment; loss of access to indigenous foods; loss of water } \\
\text { quality }\end{array}$ & 43 \\
\hline $\begin{array}{l}\text { Water pollution from domestic and } \\
\text { livestock waste }\end{array}$ & $\begin{array}{l}\text { Solid waste disposal problems; inadequate sanitation; faecal } \\
\text { contamination of water and bacterial disease from poor waste } \\
\text { disposal }\end{array}$ & $23,27,38,39,40,41$ \\
\hline $\begin{array}{l}\text { Contamination of food web, and threat of } \\
\text { contamination, from industrial } \\
\text { development, mining, herbicide } \\
\text { spraying, nuclear power facilities }\end{array}$ & $\begin{array}{l}\text { Pollution and chemical contamination from mining, oil drilling and } \\
\text { petrochemical development; toxic residues in food }\end{array}$ & $27,35,38,40,44$ \\
\hline Soil erosion and deterioration & $\begin{array}{l}\text { Decline in soil fertility; soil loss; overgrazing and reduced carrying } \\
\text { capacity for livestock; deterioration of pastures }\end{array}$ & $40,41,45$ \\
\hline Global climate change & $\begin{array}{l}\text { Melting glacial ice and sea ice (in the north); changes in rainfall } \\
\text { patterns; weather extremes, floods; raised sea levels }\end{array}$ & $\begin{array}{l}23,27,35,38,39 \\
40,41,44\end{array}$ \\
\hline
\end{tabular}

${ }^{*}$ Adapted from reference 31 . 
food systems for the cultures in the programme. Issues recorded by case study partners ${ }^{(8,11,15)}$ are noted in the categories of: (i) erosion of biodiversity of both wild and cultivated species of animals and plants; (ii) destruction of forests, water shortages and hydroelectric dam construction; (iii) water pollution from domestic and livestock waste; (iv) contamination of lands, water and food species from industrial development; and (v) climate change. While not a complete list of the unfortunate ecosystem challenges of many Indigenous Peoples in the world today, it echoes the mounting larger world order of deterioration in global ecosystems. Especially of note to add to this list are the threats to fragile coastal waterways from uncontrolled industrialization and discharge of industrial by-products ${ }^{(16,17)}$ and enforcement of conservation strategies that prevent harvest of nutritionally rich wildlife by Indigenous Peoples ${ }^{(18)}$.

For Indigenous Peoples to reverse the deterioration they see in their food systems, and to contribute to food system sustainability, activism for cultural renewal and ecosystem restoration is an important part of the picture.

Healthy and sustainable food systems for Indigenous Peoples that support food security in the long term require attention to the interconnected principles of nature, food and culture. 'Nature' refers to intact and diverse ecosystems that provide strong and well-balanced food webs. Intact cultures require institutions that sustain healthy food and nutrition that support physical, mental, emotional and spiritual health and well-being. Support for indigenous stewardship and management of their ecosystems, usually in partnership with others, helps to ensure food diversity and sustainable diets. This requires strong community leadership and social institutions, with support and cooperation from governments, non-governmental organizations and individuals at the community level, so that traditional territories continue to be accessed and cared for.

\section{Encouraging food system sustainability among Indigenous Peoples}

Important findings of the research were documentation of the many food species still known in the twelve rural cultural areas. However, the extent of use of these foods varied greatly depending on the ecosystem, its threats and cultural strength. Data analysis of the two dietary components (traditional foods and commercial foods) gave the extent of use and energy contributions of the local species/varieties in contrast to that coming from purchased or donated foods. For example, more than 380 local species/varieties were reported by respondents in the Pohnpei culture in the Federated States of Micronesia and the Karen in Western Thailand, whereas there were thirty-five traditional food species being used in the drought-prone areas of the Maasai, Kenya. While Maasai in Kajaido District consumed only about $6 \%$ of their dietary energy as traditional foods, about $27 \%$ of energy of those in Mand community in Pohnpei came from traditional foods, and over $90 \%$ of dietary energy came from the local food resources of the Peruvian Awajún and the Igbo in Nigeria ${ }^{(8,14)}$. The remaining dietary energy to complete daily energy intakes was from purchased foods. The mix of traditional foods and purchased foods that provides the individual dietary energy budget shifted depending on seasonal and climate change as well as on social and economic change.

It is reasonable to review the two dietary portions as separate entities when considering food system sustainability at the local level. Obviously, it is easier for communities to consider management of local resources to promote their sustainability than it is to address the many factors impacting purchased foods generated by distant globalized markets subject to the forces of international economies and trade regulations. By making food choices within the local food system contributed by harvesters and farmers who experience and maintain the natural land and forest productivity, Indigenous Peoples contribute to promotion of sustainable diets with this significant dietary portion for health and nutrition of their communities. Maintaining local food systems with their food species diversity is important for resilience of communities faced with climate or economic stresses, such as escalation in food prices.

\section{Traditional food system sustainability}

At the local level, traditional food sustainability exists when ecosystems continue to provide resources in ways that ensure conservation and longevity of the species/varieties in their natural setting. Harvesting is done in ways that do not exhaust the resource and provides for regeneration. Agriculture is conducted on a small scale and is friendly to organic methods, without providing chemical and/or biological contaminants that pollute lands, water or air, and farmers are in close contact with and knowledgeable about the land. Similar considerations hold for hunters and fishers. Harvested foods are shared in the communities and waste is minimized.

Overall, the programme demonstrated many ways that close attention to local food systems can impact community knowledge building, which results in outcomes of improved local food use in local diets and improved nutrition. As well, local programme leaders showed a diversity of ways to motivate communities and contribute to policies that sustain local ecosystems ${ }^{(19,20)}$.

While strategies necessarily varied by culture, community and ecosystem, efforts focused mainly on how to increase consumption of the local foods; this stimulated community protection of the food resources to ensure their sustained availability.

Improving local availability and access to cultural biodiverse foods notably occurred in three case studies In the Inga case study ${ }^{(21)}$ of Indigenous Peoples in Colombia, food system promoters identified key traditional foods to promote for food and medicinal value. Areas were cleared for cultivating the foods, seeds exchanged and culinary festivals held with the harvest according to cultural values. 
Local schools on the indigenous reserves prepared menus using the harvested foods, and other educational activities were developed using the traditional foods. An important contribution to food system sustainability for the Inga is the expansion of ancestral territories in the Alto Fragua Indi Wasi National Park, part of the protected Colombian national park system. The Yurayaco and San Miguel indigenous reserves also became co-managed protected areas for subsistence traditional food and medicine harvests of the Inga and other Indigenous Peoples in the area.

The Karen of Sanephong, Kanchanaburi Province in Western Thailand ${ }^{(22)}$ had the objective of providing more of their local cultural foods to families by increasing awareness of the importance of traditional Karen foods and promoting them especially among children in schools. Children and youth were taught how to find the foods growing in the forest and to prepare community gardens, and then to harvest and prepare the foods they harvested. Men and women in the community were encouraged to gather foods from natural sources and to increase the range and year-round availability of foods.

In the case study in Pohnpei, Federated States of Micronesia, access to local foods was enhanced through agriculture of traditional species ${ }^{(23)}$. The local agricultural extension service developed nurseries of several banana cultivars and lemongrass, breadfruit, sweet coconut, soursop and citrus, with seedlings being distributed to farmers and other interested people who could plant these crops near their homes in the village, thus promoting crop sustainability.

Improving knowledge of how to use traditional foods was a strategy of several of the case studies that

increased cultural pride, care and demand for the foods The Nuxalk Food and Nutrition Program that was conducted in the $1980 \mathrm{~s}$ and recently reviewed ${ }^{(24)}$ described how elders promoted greater use of traditional fish by helping families build the small cabins to smoke fish, and by providing pressure canners and teaching how to safely preserve fish. The project assistants conducted fitness activities and gave classes on traditional foods in the schools on the reserve. They also helped prepare two handbooks distributed to all households that described (i) each species elders recalled as important and (ii) a recipe book that uses both traditional and market foods. Both handbooks continue to be reprinted and used.

The Inuit in Pangnirtung recorded elders describing how traditional foods are harvested, preserved and prepared. These recordings were shared on radio and in the schools in the village, and are a permanent record for the community ${ }^{(25)}$.

In the broad programme conducted in Pohnpei, Micronesia, educational activities about traditional species were, and are still, conducted in schools, with women's groups and through extensive media coverage - radio, television and newsletters. This supplemented the increased cultivation of species that the agricultural extension service was instrumental in developing on the islands ${ }^{(23)}$.
Educators participating with the Ainu programme in Hokkaido, Japan, conducted several traditional food preparation classes especially targeted to youth which incorporated both traditional and commercial foods. Community newsletters and activities to prepare traditional Ainu foods for community celebrations were published and distributed, and are still in use ${ }^{(26)}$.

In the eight participating Awajún communities ${ }^{(27)}$, central nurseries were created to provide seeds and seedlings by the women's group, and fish ponds and small animal food compounds (chickens, guinea pigs, pigs) were built to increase animal food provisions. Thirty-two elected health workers were trained in food and health activities. Workshops were held on how to maintain the nurseries, fish ponds and small animal compounds, and also on general nutrition topics and cultural food preparations. Posters about the foods and a book describing traditional species were presented to each community centre, the research institute in Lima and the national library.

\section{Cross-sectoral planning to enhance food system sustainability and food security of Indigenous Peoples}

To improve sustainability of food systems and the food security they can provide, case study partners recognized that many aspects of society and governments need to be committed to the effort and provide resources and encouragement to those promoting food systems at the local level. Several suggestions on implementing this are summarized below.

\section{Include policy stakebolders from different disciplines and government sectors at all levels for shared responsibility: local, state, national, international governments and non-governmental organizations} Because Pohnpei is a state within the relatively small country of Micronesia, several offices in relevant ministries at both state and national level easily collaborated in the central town of Kolonia to increase visibility and use of traditional foods. Especially promoted through agriculture and agriculture extension, collaboration was also relevant in departments of health, culture, environment, social affairs, finance, international affairs and tourism. Peace Corps volunteers were included in activities with the non-governmental organization, Island Food Community of Pohnpei, and visits from ambassadors of several countries (notably Japan and the USA) participated in traditional food events. The national philatelic bureau that issues postage stamps featured several species of traditional foods, especially bananas, on stamps used throughout the country. The Governor of Pohnpei State and the President of Micronesia both promoted use of traditional foods and cultural dishes at official events ${ }^{(23)}$.

An example from the Karen community of Sanephong in Thailand showed that local health workers and border control officers joined with school teachers to share in cultural 
activities. The royal family of Thailand was represented by Princess Sirindhorn in several activities of schoolchildren in Sanephong and continues to give important national moral support to the community for its progress in protecting traditional food use for the health benefits to children ${ }^{(22)}$.

\section{Joint management of cultural food resources; capacity building}

An example of cooperation among indigenous leaders and non-indigenous government to conduct joint management of wildlife resources is exemplified in Gwich'in and Inuit examples in Canada. Since endangered wildlife species are affected by climate events and harvesting strategies, their management benefits from careful consideration by natural resources officers and indigenous leaders. Youth in both areas, trained for participation in wildlife management activities, were positive examples of building cooperation in management and harvest of wildlife ${ }^{(25,28)}$.

The Pangnirtung Inuit and Nuxalk case communities live in coastal areas and have been active in management and conservation of these fragile ecosystems. Nuxalk initiatives include creation of the coastal guardian watchmen network $^{(29)}$, conferences and regular radio programmes, the Wild Salmon Warrior Radio ${ }^{(30)}$. In particular, the network engages in capacity building with attention to care and monitoring the health of key food species, particularly salmon, and habitat protection ${ }^{(29)}$.

\section{Foster bealthy and affordable foods from commercial markets}

Because all communities of Indigenous Peoples have food systems that contain both traditional and commercial foods, the importance of knowing about the benefits of wise shopping of commercial foods was recognized. For example, in Pohnpei mothers were taught the limited nutritional benefits of refined white rice, particularly if it is not enriched, in contrast to the many species of widely available staple carbohydrate foods such as taro, breadfruit, yam and banana ${ }^{(23)}$. In the Nuxalk case study, classes were conducted by the trained project assistants about wise food shopping and helped drive a demand for healthier foods to be available in the local Co-Op food store. The result was that families harvested and used more traditional foods, reduced their monthly food costs and therefore reduced their percentage of annual income spent on food ${ }^{(24)}$.

\section{Use schools and universities, leaders and media personalities to build global consciousness}

Throughout the discussions and interventions, case study leaders emphasized that having prominent figures promote the food systems projects was important for building local contributions to global consciousness for sustaining the environments that provide their local foods. In the Nuxalk Food and Nutrition Program the elected and hereditary chiefs, the elected Council members and key elders in the community presented consistent messages to uphold the programme with their knowledge and activities with local food harvest, preparation and use. A local fitness personality from British Columbia television visited the community and stimulated awareness of good diet and regular fitness for good health. This emboldened the school teachers to continue the messaging and for students to carry the message home to entire extended families. Schools were always a key resource for giving nutrition and health messages to students at all levels, which included better understanding of both the traditional component and the store food component of food systems. The programme demonstrated how using more traditional Nuxalk food reduced family food expenditures, as noted earlier ${ }^{(24,31)}$.

In several case studies students from communities were encouraged and helped to attend higher education. Graduate students who assisted the projects from national and international universities helped in many ways to share knowledge about the benefits of protecting ecosystems and culture for health benefits to communities locally and globally ${ }^{(11)}$.

\section{Reflections}

The networks of partnerships that created the Indigenous Peoples' Food Systems for Health programme offer reflections on how Indigenous Peoples' collective heritage and knowledge give voice to inform global policies for sustainable food systems and food security. While Indigenous Peoples' food systems were necessarily sustainable before colonization, the modern circumstances in which Indigenous Peoples live today require careful thought and management to not only protect the biodiversity of foods known and used in rural areas in which Indigenous Peoples live, but also to ensure that human rights, food sovereignty and food security in the contemporary world provide a healthy combination of both traditional cultural foods and commercial foods ${ }^{(32,33)}$.

With about $50 \%$ of all people, including Indigenous Peoples, now living in urban environments, residents remaining in rural homelands must be supported so that traditions and local food species can be protected. Efforts to document Indigenous Peoples' food systems have shown the vast biodiversity in foods known and used in the past and at the present time. But with erosion of local biodiversity in food systems due to ecosystem threats and inclusion of ever-increasing amounts of industrially produced foods, often of poor nutritional quality, it is important to sustain local foods in local diets. Ecosystem protection is essential, as is cultural resilience to maintain food traditions, while using food markets at their affordable and nutritional best ${ }^{(34)}$.

This programme of activities conducted with support from the UN system and the IUNS has contributed to policies in the FAO on the right to food for Indigenous Peoples. It has also been instrumental in bringing public consciousness to food security and nutrition issues of Indigenous 
Peoples for the UN Permanent Forum on Indigenous Issues (UNPFII); the launch of the 2013 publication ${ }^{(11)}$ took place in New York City with the UNPFII. Results of the programme were presented at the Arctic Futures Symposium of the International Polar Foundation in Brussels in 2013; at the Asia and Pacific Symposium on Sustainable Diets in Ulaanbaatar in 2013; and at the IUNS International Congress of Nutrition in Granada in 2013. Our results and publications have also contributed to background information for considerations on the agreements and international commitments reached at the UN World Conference on Indigenous Peoples in September 2014 and at the Convention of the Parties of the UN Convention of Biological Diversity in Korea in October $2014^{(20,34)}$.

The complex and interacting determinants of cultural, social, economic and environmental change that affect food systems of all people must be considered holistically by policy makers at all levels. Looking to Indigenous Peoples' food systems and seeking to understand and promote sustainable food systems by and for the people directly involved will contribute to global consciousness and the imperative for a sustainable planet that provides food for the health and well-being of everyone. As the UN system develops the Sustainable Development Goals of 2015, attention must be given to the wealth of knowledge of Indigenous Peoples and their human right to dignity and contributions to recognizing biodiverse food systems. It is when diets are culturally acceptable, derived from sustainable ecosystems and composed of foods that are accessible to provide nutritionally adequate diets that we can identify a sustainable food system. Understanding and maintaining this balance is the key knowledge that successful Indigenous Peoples' food systems have to offer.

\section{Key lessons learned}

1. Documenting Indigenous Peoples' local food systems for scientific identifications and nutrient composition is essential for sharing knowledge of food system benefits.

2. Building capacity at the local level to share new scientific knowledge with traditional knowledge about food system species fosters pride in the food system.

3. Traditional knowledge on ecosystem resources can be used for food security, livelihoods and health, and is a major part of indigenous identity.

4. Indigenous Peoples suffer from dispossession of their land and resources, and face discrimination and serious health disparities within their countries. These negative social influences must be recognized and addressed.

\section{Key messages}

1. Food security is an essential component of nutrition security, health and well-being.
2. Conservation of natural resources needs to be built into policies derived with participation of indigenous communities that contribute to and use these resources.

3. Traditional food system protection for health benefits to communities should be balanced with increased access to accessible good-quality commercial foods.

4. Understanding Indigenous Peoples' circumstances fully requires interdisciplinary collaboration to include the community perspective: nutritionists, food scientists, anthropologists, epidemiologists and policy analysts. Intersectoral (ministries of health, agriculture, trade, education, culture, etc.) collaboration within local, national and international governments is essential to address the many influences on nutrition and unique issues faced by Indigenous Peoples.

\section{Good practices for public bealth and nutrition practitioners and policy makers}

1. Identify and address disparities faced by Indigenous Peoples.

2. Address improvements in local and national policies to reduce threats to and protect ecosystems and their resources and the Indigenous Peoples living in their inherent territories.

3. Respect traditional knowledge of Indigenous Peoples and include them in development programmes that affect their traditional food systems and health.

4. Contribute new knowledge on local food species identifications and nutrient composition for use in nutrition education programmes and health promotion activities and for planning and using biodiversity for nutrition. Always address nutrition improvements with food-based approaches.

5. Include Indigenous Peoples and their 'free, prior and informed consent' for resource development within their territories.

6. National food security strategies should demonstrate awareness and support for the role of traditional foods to address food security issues of Indigenous Peoples.

\section{Acknowledgements}

Acknowledgements: To the many colleagues and members of communities of Indigenous Peoples who contributed to the work of the CINE programme over the last decade, and more, I express my sincere thanks. Especially relevant to this contribution I recognize the community leaders and academic partners and their collaborators who shared their expertise for discussion at our 2008 Bellagio conference to understand and create the methods for fostering sustainable food systems for Indigenous Peoples. In particular, I express sincere appreciation to: Chief Bill Erasmus (Dene Nation and Assembly of First Nations, Canada); Grace Egeland and Looee Okalik (Inuit case study, Canada); Irma (Chinita) Tuesta, Hilary Creed-Kanashiro, Miluska Carrasco and Melissa 
Abad (Awajún case study, Peru); Bill Tallio and Nancy J. Turner (Nuxalk case study, Canada); Sonia Caicedo, Ana Maria Chaparro and Antonia Mutumbojoy (Inga case study, Colombia); (the late) Lois Englberger, Adelino Lorens, Podis Pedris and Kiped Albert (Pohnpei case study, Federated States of Micronesia); Sinee Chotibooriboon, Mailong-ong Sangkhachalatarn, Solot Sirisai, Lakana Daoratanahong, Prapasri Puwastien, Sakorn Dhanamitta and Suttilak Smitasiri (Karen case study, Thailand); Buduru Salomeyesudas and Periyapatna V. Satheesh (Dalit case study, India); Joseph ole Simel, Tim Johns, Ephraim Mukisira and Ruth Oniang'o (Maasai case study, Kenya); Rhonda Francis (Gwich'in case study, Canada); Lalita Bhattacharjee, Gopa Kothari, Motirim Chaudhury and Biplab Nandi (Bhil case study, India); (the late) Elizabeth (Chinwe) Okeke and Henrietta Ene-Obong (Igbo case study, Nigeria); Masami Iwasaki-Goodman, Koichi Kaizawa and Miwako Kaizawa (Ainu case study, Japan); Li Dan and Fengying Zhai (Miao case study, China); Salek Ahmed and Farida Akhter (Mogh case study, Bangladesh); Grace Marquis (CINE, Canada); Marion Roche (CINE, Canada); Siri Damman (Oslo, Norway); and Gail G. Harrison (University of California at Los Angeles, USA). I am especially appreciative of the good work of Dina Spigelski (CINE, Canada), the assistant for the overall programme, who compiled the comments from the partners as a first step towards this contribution. Financial support: Support for the conference that derived the information in this contribution came from The Rockefeller Foundation Bellagio Conference Center, the Canadian Institutes of Health Research and the FAO. Conflict of interest: None. Authorship: While the academic leader of the programme is the author of the paper, due consideration must be given to all the case study partners for their contributions, as noted above. Ethics of human subject participation: All research contributing to the case studies and their conferences from 2000 to 2009 were approved for human subject ethics by McGill University.

\section{References}

1. Food and Agriculture Organization of the United Nations, International Fund for Agricultural Development \& World Food Programme (2013) The State of Food Insecurity in the World, 2013. The Multiple Dimensions of Food Security. Rome: FAO.

2. World Health Organization (2013) Obesity and Overweight. Fact Sheet no. 311. Geneva: WHO; available at http://www. who.int/mediacentre/factsheets/fs311/en/index.html

3. Khoury CK, Bjorkman AD, Dempewolf $\mathrm{H}$ et al. (2014) Increasing homogeneity in global food supplies and the implications for food security. Proc Natl Acad Sci US A 111, 4001-4006.

4. Masset G, Soler L-G, Vieux F et al. (2014) Identifying sustainable foods: the relationship between environmental impact, nutritional quality, and the prices of foods representative of the French diet. J Acad Nutr Diet 114, 862-869.

5. Johnston JL, Fonzo JC \& Cogill B (2014) Understanding sustainable diets: a descriptive analysis of the determinants and processes that influence diets and their impact on health, food security, and environmental sustainability. $A d v$ Nutr 5, 418-429.

6. Burlingame B (2014) Grand challenges in nutrition and environmental sustainability. Front Nutr 1, 3.

7. Department of Economic and Social Affairs of the United Nations Secretariat (2009) State of the World's Indigenous Peoples. New York: UN.

8. Kuhnlein HV, Erasmus B \& Spigelski D (2009) Indigenous Peoples' Food Systems: The Many Dimensions of Culture, Diversity and Environment for Nutrition and Health. Rome: FAO and Centre for Indigenous Peoples' Nutrition and Environment.

9. Burlingame B \& Dernini S (2012) Sustainable Diets and Biodiversity. Rome: FAO.

10. Kuhnlein HV, Erasmus B, Creed-Kanashiro H et al. (2006) Indigenous Peoples' food systems for health: finding interventions that work. Public Health Nutr 9, 1013-1019.

11. Kuhnlein HV, Erasmus B, Spigelski D et al. (editors) (2013) Indigenous Peoples' Food Systems and Well-being: Interventions and Policies for Healthy Communities. Rome: FAO and Centre for Indigenous Peoples' Nutrition and Environment.

12. Centre for Indigenous Peoples' and Environment (2014) About CINE. http://www.mcgill.ca/cine/about (accessed April 2014).

13. Kuhnlein HV, Smitasiri S, Yesudas S et al. (2006) Documenting Traditional Food Systems of Indigenous Peoples: International Case Studies. Guidelines for Procedures. Montreal: Centre for Indigenous Peoples' Nutrition and Environment, McGill University; available at http://www. mcgill.ca/files/cine/manual.pdf

14. Kuhnlein HV (2012) Biodiversity and sustainability of Indigenous Peoples' foods and diets. In Sustainable Diets and Biodiversity: Directions and Solutions for Policy, Research and Action. Proceedings of the International Scientific Symposium: Biodiversity and Sustainable Diets United Against Hunger, 3-5 November, 2010, pp. 118-124 [B Burlingame and S Dernini, editors]. Rome: FAO.

15. Turner NJ, Plotkin M \& Kuhnlein HV (2013) Global environmental challenges to the integrity of Indigenous Peoples' food systems. In Indigenous Peoples' Food Systems and Well-being: Interventions and Policies for Healthy Communities, pp. 23-38 [HV Kuhnlein, B Erasmus, D Spigelski et al., editors]. Rome: FAO and Centre for Indigenous Peoples' Nutrition and Environment.

16. Tilsted SH (2013) Fish diversity and fish consumption in Bangladesh. In Diversifying Food and Diets: Using Agricultural Biodiversity to Improve Nutrition and Health. Issues in Agricultural Biodiversity, pp. 257-269 [J Fanzo, D Hunter, T Borelli et al., editors]. London: Earthscan.

17. Toppe J, Bondad-Reantaso MG, Hassan MR et al. (2012) Aquatic biodiversity for sustainable diets: the role of aquatic foods in food and nutrition security. In Sustainable Diets and Biodiversity pp. 94-101 [B Burlingame and S Dernini, editors]. Rome: FAO.

18. Golden CD, Fernald LCH, Brashares JS et al. (2011) Benefits of wildlife consumption to child nutrition in a biodiversity hotspot. Proc Natl Acad Sci US A 108, 19653-19656.

19. Kuhnlein $H$ (2013) What food system intervention strategies and evaluation indicators are successful with Indigenous Peoples? In Indigenous Peoples' Food Systems and Wellbeing: Interventions and Policies for Healthy Communities, pp. 237-256 [HV Kuhnlein, B Erasmus, D Spigelski et al., editors]. Rome: FAO and Centre for Indigenous Peoples' Nutrition and Environment.

20. Kuhnlein H, Erasmus B, Spigelski D et al. (2013) Indigenous Peoples' food systems (Commentary). World Nutr $\mathbf{4}$, 488-513.

21. Caicedo S \& Chaparro AM (2013) Inga food and medicine systems to promote community health. In Indigenous Peoples' Food Systems and Well-being: Interventions and 
Policies for Healthy Communities, pp. 121-141 [HV Kuhnlein, B Erasmus, D Spigelski et al., editors]. Rome: FAO and Centre for Indigenous Peoples' Nutrition and Environment.

22. Sirisai S, Chotiboriboon S, Tantivatanasathien P et al. (2013) Culture-based nutrition and health promotion in a Karen community. In Indigenous Peoples' Food Systems and Wellbeing: Interventions and Policies for Healthy Communities, pp. 159-177 [HV Kuhnlein, B Erasmus, D Spigelski et al., editors]. Rome: FAO and Centre for Indigenous Peoples' Nutrition and Environment.

23. Englberger L, Lorens A, Pedrus P et al. (2013) Let's Go Local! Pohnpei promotes local food production and nutrition for health. In Indigenous Peoples' Food Systems and Wellbeing: Interventions and Policies for Healthy Communities, pp. 191-220 [HV Kuhnlein, B Erasmus, D Spigelski et al., editors]. Rome: FAO and Centre for Indigenous Peoples' Nutrition and Environment.

24. Kuhnlein HV \& Moody SA (1989) Evaluation of the Nuxalk Food and Nutrition Program: traditional food use by a Native Indian group in Canada. J Nutr Educ 21, 127-132.

25. Egeland GE, Yohannes S, Okalik L et al. (2013) The value of Inuit elders' storytelling to health promotion during times of rapid climate changes and uncertain food security. In Indigenous Peoples' Food Systems and Well-being: Interventions and Policies for Healthy Communities, pp. 141158 [HV Kuhnlein, B Erasmus, D Spigelski et al., editors]. Rome: FAO and Centre for Indigenous Peoples' Nutrition and Environment.

26. Iwasaki-Goodman M (2013) Tasty tonoto and not-so-tasty tonoto: fostering traditional food culture among the Ainu people in the Saru River region, Japan. In Indigenous Peoples' Food Systems and Well-being: Interventions and Policies for Healthy Communities, pp. 221-236 [HV Kuhnlein, B Erasmus, D Spigelski et al., editors]. Rome: FAO and Centre for Indigenous Peoples' Nutrition and Environment.

27. Creed-Kanashiro HM, Carrasco M, Melissa A et al. (2013) Promotion of traditional foods to improve the nutrition and health of the Awajún of the Cenepa River in Peru. In Indigenous Peoples' Food Systems and Well-being: Interventions and Policies for Healthy Communities, pp. 53-74 [HV Kuhnlein, B Erasmus, D Spigelski et al., editors]. Rome: FAO and Centre for Indigenous Peoples' Nutrition and Environment.

28. Kuhnlein HV, Goodman L, Receveur O et al. (2013) Gwich'in traditional food and health in Tetlit Zheh, Northwest Territories, Canada: Phase II. In Indigenous Peoples' Food Systems and Well-being: Interventions and Policies for Healthy Communities, pp. 101-120 [HV Kuhnlein, B Erasmus, $\mathrm{D}$ Spigelski et al., editors]. Rome: FAO and Centre for Indigenous Peoples' Nutrition and Environment.

29. Coastal First Nations Great Bear Initiative (2014) Guardian Watchmen Programs: Nuxalk. http://coastalguardianwatch men.ca/nation/nuxalk (accessed September 2014).

30. Nuxalk Radio (2014) Wild Salmon Warrior Radio. http:// nuxalkradio.com/programs/wild-salmon-warrior-radio (accessed September 2014).

31. Turner NJ, Tallio WR, Burgess S et al. (2013) The Nuxalk Food and Nutrition Program for Health revisited. In Indigenous Peoples' Food Systems and Well-Being: Interventions and Policies for Healthy Communities, pp. 177-190 [HV Kuhnlein, B Erasmus, D Spigelski et al., editors]. Rome: FAO and Centre for Indigenous Peoples' Nutrition and Environment.

32. Mowforth M (2014) Indigenous people and the crisis over land and resources. The Guardian, 23 September. http:// www.theguardian.com/global-development/2014/sep/23/ indigenous-people-crisis-land-resources (accessed September 2014).

33. Ford L (2014) Indigenous groups give cautious welcome to deal struck at UN. The Guardian, 23 September. http:// www.theguardian.com/global-development/2014/sep/23/ indigenous-groups-cautious-welcome-deal-united-nations (accessed September 2014).

34. Kuhnlein H, Burlingame B \& Erasmus B (2013) Policy and strategies to improve nutrition and health for Indigenous Peoples. In Indigenous Peoples' Food Systems and Wellbeing: Interventions and Policies for Healthy Communities, pp. 279-295 [HV Kuhnlein, B Erasmus, D Spigelski et al., editors]. Rome: FAO and Centre for Indigenous Peoples' Nutrition and Environment.

35. Egeland GM, Charbonneau-Roberts G, Kuluguqtuq J et al. (2009) Back to the future: using traditional food and knowledge to promote a healthy future among Inuit. In Indigenous Peoples' Food Systems: The Many Dimensions of Culture, Diversity and Environment for Nutrition and Health, pp. 9-22 [HV Kuhnlein, B Erasmus and D Spigelski, editors]. Rome: FAO and Centre for Indigenous Peoples' Nutrition and Environment.

36. Turner NJ, Harvey T, Burgess SA et al. (2009) The Nuxalk food and nutrition program, Coastal British Columbia, Canada: 1981-2006. In Indigenous Peoples' Food Systems: The Many Dimensions of Culture, Diversity and Environment for Nutrition and Health, pp. 23-44 [HV Kuhnlein, B Erasmus and D Spigelski, editors]. Rome: FAO and Centre for Indigenous Peoples' Nutrition and Environment.

37. Chotibooriboon S, Tamachotipong S, Sirisai S et al. (2009) Thailand: food system and nutritional status of indigenous children in a Karen community. In Indigenous Peoples' Food Systems: The Many Dimensions of Culture, Diversity and Environment for Nutrition and Health, pp. 159-184 [HV Kuhnlein, B Erasmus and D Spigelski, editors]. Rome: FAO and Centre for Indigenous Peoples' Nutrition and Environment.

38. Creed-Kanashiro HM, Roche M, Cerron IT et al. (2009) Traditional food system of an Awajún community in Peru. In Indigenous Peoples' Food Systems: The Many Dimensions of Culture, Diversity and Environment for Nutrition and Health pp. 59-82 [HV Kuhnlein, D Spigelski and B Erasmus, editors]. Rome: FAO and Centre for Indigenous Peoples' Nutrition and Environment.

39. Englberger L, Lorens A, Levendusky A et al. (2009) Documentation of the traditional food system of Pohnpei. In Indigenous Peoples' Food Systems: The Many Dimensions of Culture, Diversity and Environment for Nutrition and Health, pp. 109-138 [HV Kuhnlein, B Erasmus and D Spigelski, editors]. Rome: FAO and Centre for Indigenous Peoples' Nutrition and Environment.

40. Correal C, Zuluaga G, Madrigal L et al. (2009) Ingano traditional food and health: Phase 1, 2004-2005. In Indigenous Peoples' Food Systems: The Many Dimensions of Culture, Diversity and Environment for Nutrition and Health, pp. 83-108 [HV Kuhnlein, B Erasmus and D Spigelski, editors]. Rome: FAO and Centre for Indigenous Peoples' Nutrition and Environment.

41. Oiye S, Ole Simel J, Oniang'o R et al. (2009) The Maasai food system and food and nutrition security. In Indigenous Peoples' Food Systems: The Many Dimensions of Culture, Diversity and Environment for Nutrition and Health, pp. 231-250 [HV Kuhnlein, B Erasmus and D Spigelski, editors]. Rome: FAO and Centre for Indigenous Peoples' Nutrition and Environment.

42. Salomeyesudas B \& Satheesh PV (2009) Traditional food system of Dalit in Zaheerabad Region, Medak District, Andhra Pradesh, India. In Indigenous Peoples' Food Systems: The Many Dimensions of Culture, Diversity and Environment for Nutrition and Health, pp. 185-208 [HV Kuhnlein, B Erasmus and D Spigelski, editors]. Rome: FAO and Centre for Indigenous Peoples' Nutrition and Environment. 
43. Iwasaki-Goodman M, Ishii S \& Kaizawa T (2009) Traditional food systems of Indigenous Peoples: the Ainu in the Saru River Region, Japan. In Indigenous Peoples' Food Systems: The Many Dimensions of Culture, Diversity and Environment for Nutrition and Health, pp. 139-158 [HV Kuhnlein, B Erasmus and D Spigelski, editors]. Rome: FAO and Centre for Indigenous Peoples' Nutrition and Environment.

44. Kuhnlein HV, McDonald M, Spigelski D et al. (2009) Gwich'in traditional food for health: Phase 1. In Indigenous Peoples' Food Systems: The Many Dimensions of Culture, Diversity and Environment for Nutrition and Health, pp. 45-58 [HV Kuhnlein, B Erasmus and D Spigelski, editors]. Rome: FAO and Centre for Indigenous Peoples' Nutrition and Environment.

45. Okeke EC, Ene-Obong HN, Uzuegbunam AO et al. (2009) The Igbo traditional food system documented in four states in Southern Nigeria. In Indigenous Peoples' Food Systems: The Many Dimensions of Culture, Diversity and Environment for Nutrition and Health, pp. 251-282 [HV Kuhnlein, B Erasmus and D Spigelski, editors]. Rome: FAO and Centre for Indigenous Peoples' Nutrition and Environment. 